\title{
THERMOFRACTOGRAPHY OF HUMIC SUBSTANCES
}

\author{
F. J. González-Vila, F. Martín, C. Sáiz-Jiménez, \\ and H. H. *Nrmz
}

Centro de Edafologia y Biología Aplicada del Cuarto C. S. I. C., Apartado 1052, Sevilla, Spain

*Polymer Institut der Universität, Karlsruhe, Hertzstrasse, 16.75 Karlsruhe 21. W. Germany

(Received October 18, 1977; in revised form April 5, 1978)

\begin{abstract}
Thermofractography (TF) has been applied to humic and fulvic acids from four different soil types. Among the thermal products, 3,5-dihydroxybenzoic acid, catechol, 5-hydroxymethylfurfural, vanillin, phenol, furfural, guaiacol and indole were identified. These are typical fragments from lignins, microbial polyphenols, polysaccharides and proteins.

Thermofractography appears to be an effective method for study of humic molecule structures by thermal degradation. Furthermore, it seems promising to differentiate humic acids from distinct soil types and to distinguish between humic and fulvic fractions.
\end{abstract}

Humic substances are amorphous, dark-coloured, hydrophilic, acidic, polydisperse substances of high molecular weight, which are widely distributed in soils, natural waters, marine and lake sediments, peats and coals. Based on their solubilities in alkali and acid, they are usually divided into three main fractions: humic acid (HA), fulvic acid (FA) and humin.

Several physical and chemical methods have been applied to investigate the complex structures of humic substances. Among these, thermogravimetry (TG), differential thermogravimetry (DTG) and differential thermal analysis (DTA) are currently applied [1,2].

Other techniques, such as flash pyrolysis coupled with gas chromatography (Py-GC) and mass spectrometry (Py-MS), permit the separation and identification of fragments arising from thermal degradation [3-6].

A suitable and rapid method for the classification of natural products, which permits good discrimination between the products, is thermofractography (TF) $[7-10]$. The sample is heated in a glass tube by a heating block at linearly increasing temperatures from 50 to $450^{\circ}$. The products are carried on a TLC plate which moves slowly, with its starting line quite near the outlet of the glass tube. This method has the advantages over Py-GCand Py-MS that it is relatively simple and no complex and refined equipment is needed.

In the present paper TF has been applied to humic and fulvic acids from four different soil types to evaluate the analytical possibilities of the method. 


\section{Material and methods}

The classification, geographical origin of the soil samples, and the analytical data of the humic fractions are listed in Table 1.

Extraction and purification of humic substances have been reported previously $[4,11]$.

Table 1

Classification and geographical origin of the soil samples, and analytical data from the humic fractions

\begin{tabular}{|c|c|c|c|c|c|c|c|c|c|}
\hline Soil, subgroup & Soil series & $\begin{array}{c}\text { Geo- } \\
\text { graphical } \\
\text { origin }\end{array}$ & $\begin{array}{l}\text { Hori- } \\
\text { zont }\end{array}$ & $\begin{array}{c}\text { Frac- } \\
\text { tion }\end{array}$ & C & $\mathbf{H}$ & $\mathbf{N}$ & o & $\begin{array}{c}\text { Vola- } \\
\text { tile } \\
\text { mate- } \\
\text { rial, } \\
\%\end{array}$ \\
\hline $\begin{array}{l}\text { Humic } \\
\text { Haplorthod }\end{array}$ & Ribadeo & N. Spain & $\mathrm{Bh}$ & $\begin{array}{l}\text { HA } \\
\text { FA }\end{array}$ & $\begin{array}{l}59.4 \\
46.2\end{array}$ & $\begin{array}{l}4.2 \\
3.4\end{array}$ & $\begin{array}{l}3.3 \\
0.8\end{array}$ & $\begin{array}{l}33.1 \\
50.5\end{array}$ & $\begin{array}{l}45.2 \\
53.1\end{array}$ \\
\hline $\begin{array}{l}\text { Andic } \\
\text { Hapludult }\end{array}$ & Las Lajas & $\begin{array}{l}\text { Tenerife } \\
\text { Island }\end{array}$ & $\mathrm{A}_{11}$ & $\begin{array}{l}\text { HA } \\
\text { FA }\end{array}$ & $\begin{array}{l}48.7 \\
40.6\end{array}$ & $\begin{array}{l}4.8 \\
4.1\end{array}$ & $\begin{array}{l}3.8 \\
1.4\end{array}$ & $\begin{array}{l}42.7 \\
53.9\end{array}$ & $\begin{array}{l}46.3 \\
55.0\end{array}$ \\
\hline $\begin{array}{l}\text { Lythic } \\
\text { Udorthent }\end{array}$ & Arroyomolinos & $\begin{array}{l}\text { S. W. } \\
\text { Spain }\end{array}$ & $A_{1}$ & $\begin{array}{l}\text { HA } \\
\text { FA }\end{array}$ & $\begin{array}{l}52.2 \\
43.1\end{array}$ & $\begin{array}{l}5.2 \\
3.6\end{array}$ & $\begin{array}{l}3.6 \\
1.7\end{array}$ & $\begin{array}{l}39.0 \\
51.6\end{array}$ & $\begin{array}{l}52.8 \\
58.2\end{array}$ \\
\hline $\begin{array}{l}\text { Typic } \\
\text { Xerochrept }\end{array}$ & Santa Olalla & $\begin{array}{l}\text { S. W. } \\
\text { Spain }\end{array}$ & $A_{11}$ & $\begin{array}{l}\text { HA } \\
\text { FA }\end{array}$ & $\begin{array}{l}51.4 \\
47.9\end{array}$ & $\begin{array}{l}5.8 \\
5.2\end{array}$ & $\begin{array}{l}4.1 \\
2.6\end{array}$ & $\begin{array}{l}38.7 \\
44.3\end{array}$ & $\begin{array}{l}50.1 \\
53.0\end{array}$ \\
\hline
\end{tabular}

The technique and equipment were described by Stahl [7]. The experimental conditions were:

Apparatus: Tasomat (Desaga, Heidelberg, Germany). Sample weight: $10 \mathrm{mg}$. Heating rate: Linear $8^{\circ} / \mathrm{min}$ from 150 to $450^{\circ}$. Carrier gas: Nitrogen, $30 \mathrm{ml} / \mathrm{min}$, controlled by a flow meter. Speed of TLC plate: $5 \mathrm{~mm} / \mathrm{min}$.

For thin layer chromatography, silica gel $\mathrm{GF}_{254}$ plates with a layer thickness of $250 \mu \mathrm{m}$ were used.

Several solvents were employed; the best results were obtained with benzene/ ethanol $(2: 1)$, chloroform/ethyl acetate $(19: 1)$ and benzene/ethanol $(2: 1)$ followed by cyclohexane/acetone $(1: 1)$. In this paper the results shown are those obtained with chloroform/ethyl acetate $(19: 1)$, which was also used in the TF of lignins [9].

For detection the following sequence was employed: UV-light $(254 \mathrm{~nm})$, steaming with ammonia, spraying with a $1 \%$ aqueous solution of fast blue salt $B$ (Merck), spraying with concentrated $\mathrm{HCl}$. For specific detection of carbonyl compounds, a saturated $o$-dianisidine solution in glacial acetic acid was employed. The spontaneous development of colours was intensified by blowing with hot air. 


\section{Results and discussion}

Figure la shows the thermofractogram (TFG) of HA from Andic Hapludult, which is representative with slight variations for all HA samples used.

The tentative identification of the products listed in Table 2 was carried out by comparison with standard compounds. $\mathrm{R}_{f}$ values and temperature ranges in which they appear are also included.

All humic acid samples show common characteristics with regard to the thermofractographic behaviour: 1) a similar percentage of degradation, which ranges around $50 \%$ of the sample; 2) the products are released in three temperature

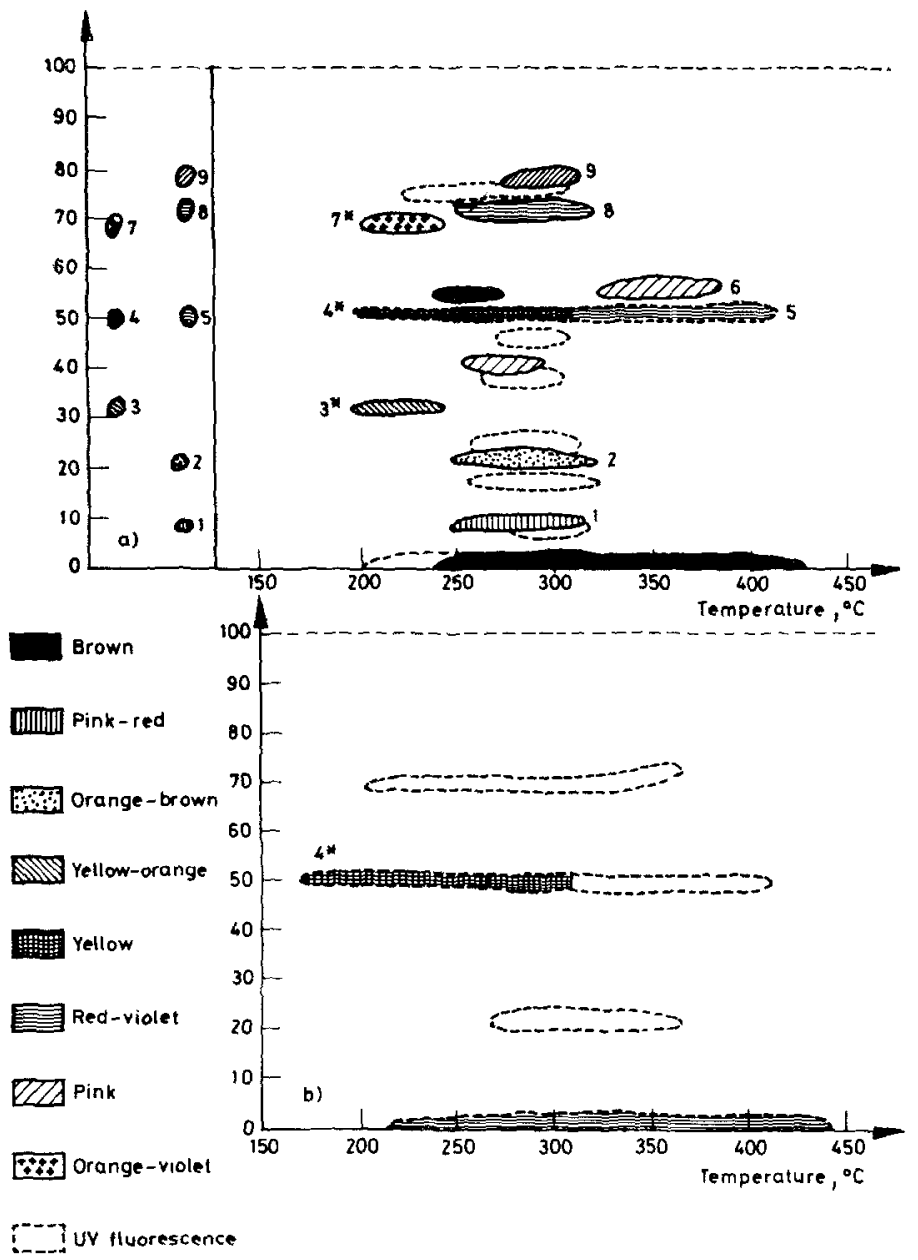

Fig. 1. a) Thermofractogram of andic hapludult humic acid. b) Thermofractogram of humic haplorthod fulvic acid. The colours are obtained after spraying with fast blue salt B and o-dianisidin (the zones marked with asterisk). The numbers refer to the substances in Table 2 
Table 2

$R_{f}$ and temperature ranges, detection and tentative identification of common products from humic fractions

\begin{tabular}{|c|c|c|c|c|}
\hline \multirow{2}{*}{$\begin{array}{l}\text { Nr. in } \\
\text { Fig.1 }\end{array}$} & \multirow{2}{*}{$\begin{array}{l}\mathbf{R} \text { and temperature } \\
\text { ranges, }{ }^{\circ} \mathbf{C}\end{array}$} & \multicolumn{2}{|c|}{ Colour reactions with } & \multirow{2}{*}{$\begin{array}{c}\text { Tentative } \\
\text { identification }\end{array}$} \\
\hline & & fast blue salt $B$ & o-dianisidin & \\
\hline 1 & $8-10(240-325)$ & pink-red & - & $\begin{array}{l}\text { 3,5-dihydroxy-- } \\
\text { benzoic acid }\end{array}$ \\
\hline 2 & $18-22(240-330)$ & orange-brown & - & catechol \\
\hline 3 & $30-32(180-240)$ & faint yellow & yellow-orange & $\begin{array}{l}\text { 5-hydroxymethyl- } \\
\text { furfural }\end{array}$ \\
\hline 4 & $48-50(200-300)$ & faint yellow & yellow & vanillin \\
\hline 5 & $49-52(300-425)$ & red-violet & - & phenol \\
\hline 6 & $55-60(325-375)$ & pink & - & $?$ \\
\hline 7 & $68-70(200-240)$ & - & orange-violet & furfural \\
\hline 8 & $69-74(250-325)$ & red-violet & - & guaiacol \\
\hline 9 & $75-80(275-325)$ & pink & - & indole \\
\hline
\end{tabular}

ranges, the first $200-250^{\circ}$, the second $250-325^{\circ}$ and the last $325-425^{\circ}$; and 3 ). the presence of some common products.

The percentages of volatile materials agree well with those found by Py-GC of humic acids [5], though the kinetics of reaction are different. This would indicate that these percentages are independent of the rate of heating.

The differential thermogravimetric curves of HA heated under nitrogen [1] show a constant loss of weight from 150 to $450^{\circ}$, which agrees with the continuous release of thermal products in TFG. The curves show only a well defined maxima at $150^{\circ}$, due to moisture elimination, and a constant rate of decomposition from 200 to $450^{\circ}$, which corresponds to the release of products. Howewer, in the TFG a separation of evolved products can be discerned, as shown in Fig. 1.

Thus, between 200 and $250^{\circ}$ furfural (7), 5-hydroxymethylfurfural (3) and vanillin (4) were released. The first two of these compounds also appear in the TF of polysaccharides and cellulose [12] and most probably arise from the polysaccharides normally found in the humic molecule [13], which are easily split off by thermal reactions. Vanillin would arise from lignin derivatives which constitute the humic molecule or which are coextracted with the humic fractions.

Most of the compounds are produced between 250 and $325^{\circ}$. These compounds fluorescent under UV-light and some of them give colour reactions; in this way 3,5-dihydroxybenzoic acid (1), catechol (2), guaiacol (8) and indole (9) were identified. 3,5-dihydroxybenzoic acid was identified as a degradation product of HA's by sodium amalgam reduction [14] and alkaline cupric oxide oxidation [15], and its presence reveals the contribution of microbial polyphenols to the building-up of humic molecules.

Catechol and guaiacol are typical fragments of lignin TF [9] and, together with vanillin, give strong evidence for the presence of lignin structural units. Catechol 
has also been found as a degradation product of HA's [16], and guaiacol has recently been detected by Py-GC-MS of HA's [17] and Py-GC of lignins [18].

Indole is a typical thermolytic fragment from the pyrolysis of proteins and humic acids [16], which confirms the presence of proteic material in the humic acids, as demonstrated by Biederbeck and Paul [19] and Martin et al. [13].

From 325 to $425^{\circ}$ some of the products released do not migrate under the chromatographic conditions used. Only phenol (5) could be identified from among the separated compounds (5) and (6). Phenol and catechol are final products of the thermal degradation of polyphenols and phenolic acids with different functional groups, which are broken and released during the heating.

There are qualitative differences between each HA TFG; thus, the zones at $R_{f}$ $40-42$ (pink) and 55-57 (brown) are only present in the Andic Hapludult HA TFG (see Fig. 1). A zone at $R_{f} 58-60$ (violet) only appears in the Typic Xerochrept HA TFG. In these three zones unknown products of a phenolic nature are found and released between 250 and $325^{\circ}$. Furthermore, the zones (2) and (6) do not appear in the Humic Haplorthod HA TFG, and the same is true with zone (9) in the Typic Xerochrept HA TFG.

Figure $1 \mathrm{~b}$ shows the Humic Haplorthod FA TFG, which is similar to those of Lythic Udorthent and Typic Xerochrept FA, but differs somewhat from the Andic Hapludult FA TFG.

FA releases fragments in the same range of temperature as HA, but the number of detected products is smaller, while the percentage of volatile materials in all FA's is higher than those obtained from the HA's of the same soil type. This result agrees well with the data of Martin [5], who found by Py-GC that the number and amount of pyrolysis products obtained was lower in FA than in HA.

Most of the products from fulvic acids were fluorescent under UV-light; of these, only vanillin was identified, except in the case of Andic Hapludult FA TFG, where furfural and phenol were also detected.

\section{Conclusions}

From the data obtained by TF the following conclusions can be inferred:

(1) According to the nature of the products (polysaccharides, proteins and lignin derivatives), TF seems to be effective to the most accessible moiety of the humic molecule, assuming that it is a random polymer of phenolic origin to which protein and polysaccharides are attached [13].

(2) The technique seems promising to differentiate HA's from distinct soil types. Furthermore, it is an easy method to distinguish between humic and fulvic fractions.

F. J. G. Y. thanks DAAD (Deutsche Akademischer Austauschdienst) for providing a grant. 


\section{References}

1. M. Schnitzer and I. Hoffman, Geochim. Cosmochim. Acta, 29 (1965) 859.

2. P. JAMBU, T. Dupuis and M. Garais, J. Thermal Anal., 8 (1974) 231.

3. R. L. Wershaw and G. E. BohNer, Geochim. Cosmochim. Acta, 33 (1969) 757.

4. F. Martin, Z. Pflanzenähr. Bodenk., (1975) 407.

5. F. MARTIN, Geoderma, 15 (1976) 253.

6. H. L. C. MbuzelaAr, K. Haider, B. R. Nagar and J. P. Martin, Geoderma, 17, (1977) 239.

7. E. STAHL, Z. Anal. Chem., 261 (1972) 11.

8. E. STAHL and F. KA RIG, Z. Anal. Chem., 265 (1973) 81.

9. E. Staht, F. Karig, U. Broegmann, H. Nimz and H. Becker, Holzforschung, 27 (1973) 89.

10. E. Stahl, in "Analytical Pyrolysis", C. E. R. Jones and C. A. Cramers Ed., Elsevier, Amsterdam, 1977.

11. F. J. González-Vila, C. Sáiz-Imménez and F. Martin, Agrochimica, 18 (1974) 164.

12. F. KARIG, Dissertation, Saarbrücken, 1973, Germany.

13. F. Martin, C. Sáiz-Jiménez and A. Cert, Soil Sci. Soc. Am. J., 41 (1977), 1114.

14. N. A. Burges, H. M. Hurst and S. B. WaLkden, Geochim. Cosmochim. Acta, 28 (1964) 1547.

15. M. SCHNITZER, Soil Biol. Biochem., 6 (1974) 1.

16. M. SCHNTTZER and S. U. KHAN, "Humic Substances in the Environment", Marcel Decker, New York, 1972.

17. F. MARTIN, personal communication.

18. O. FAIX and W. SchWEers, Holzforschung, 29 (1975) 224

19. V. O. BJederbecK and E. A. PAUL, Soil Sci., 115 (1973) 357.

RÉsumé - La thermofractographie (TF) a été appliquée à l'analyse des acides humiques et fulviques de quatre types différents de sols. L'acide 3,5-dihydroxybenzoïque, le pyrocatéchol, le 5-hydroxyméthyl-furfural, la vanilline, le phénol, le furfural, le guaacol et l'indole ont été identifiés parmi les produits de la thermolyse. Tous sont des fragments typiques des lignines, des polyphénols microbiens, des polysaccharides et des protéines.

La thermofractographie paraît être une méthode efficace pour l'étude par dégradation thermique de la structure moléculaire des substances humiques. En outre, elle semble intéressante pour différencier les acides humiques dans les types de sols particuliers et pour distinguer les fractions humiques et fulviques.

Zusammenfassung - Die Thermofraktographie (TF) wurde zur Analyse von Humin- und Fulvinsäuren aus vier verschiedenen Bodenarten eingesetzt. Unter den Produkten der Thermolyse wurden die 3,5-Dihydroxy-benzoesäure, Brenzkatechin, 5-Hydroxymethyl-furfurol, Vanillin, Phenol, Furfurol, Guaiakol und Indol identifiziert. Diese sind typische Fragmente aus Lignin, mikrobiellen Polyphenolen, Polysacchariden und Proteinen.

Die Thermofraktoraphie scheint eine wirksame Methode zum Studium der Struktur des Huminmoleküls durch thermische Zersetzung zu sein. Außerdem scheint sie auch zur Unterscheidung von Huminsäuren aus bestimmten Bodentypen und zur Unterscheidung von Humin- und Fulvinfraktionen geeignet.

Резюме - Термофрактография (ТФ) была применена для исследования гуминовых и фульвиновых кислот из четырех различных видов почвы. Среди продуктов термолиза были идентифицированы 3.5-диоксибензойная кислота, катехол, 5-оксиметил-фурфурол, ванилин, фенол, фурфурол, гваякол и индол. Эти вещества являются типичными фрагментами из лигнинов, микробных полифенолов, полисахаридов и протеинов. Очевидно, что термофрактография будет служить эффективным методом изучения структуры гуминовой молекулы с помоцью термического разрушения. Кроме того, этот метод кажется многообецағощим для различения гумшновых кислот различных видов почвы, а также для установления различий гуминовых и фульвиновых фракций. 